\title{
Kazuistyka/Case report
}

\section{Wrodzona naczyniakowatość krwotoczna rozpoznana u 13-miesięcznego dziecka: opis przypadku i przegląd literatury}

\section{Hereditary hemorragic teleangiectasia in 13-month aged children: case report and review of the literature}

\author{
Magdalena Ćwiklińska ${ }^{1, *}$, Walentyna Balwierz ${ }^{1}$, Łukasz Wyrobek ${ }^{2}$, \\ Wanda Król-Jawień ${ }^{3}$ \\ ${ }^{1}$ Klinika Onkologii i Hematologii Dziecięcej Polsko-Amerykańskiego Instytutu Pediatrii, UJ Collegium Medium, \\ Kierownik: prof. dr hab. Walentyna Balwierz, Kraków, Polska \\ ${ }^{2}$ Odział Kardiologii Dziecięcej Uniwersyteckiego Szpitala Dziecięcego w Krakowie, Kraków, Polska \\ ${ }^{3}$ Pracownia Radiologii Uniwersyteckiego Szpitala Dziecięcego w Krakowie, Kraków, Polska
}

IN F ORMACJE O ARTYKULE

Historia artykułu:

Otrzymano: 18.03.2014

Zaakceptowano: 02.04.2014

Dostępne online: 13.04.2014

Słowa kluczowe:

- wrodzona naczyniakowatość krwotoczna

- dzieci

- przetoki płucne tętniczo-żylne

Keywords:

- Hemorrhagic hereditary

telangiectasia

- Children

- Pulmonary arteriovenous malformations

\begin{abstract}
A B S T R A C T
Hereditary haemorrhagic telangiectasia (HHT) is an autosomal dominant, rare and severe disease that results from vascular dysplasia. It is characterised by recurrent epistaxis, teleangiectasias of skin and mucosa and arteriovenous malformations in: lungs, brain, liver, gastrointestinal tract and spinal cord. Diagnosis of HHT is rarely done in early childhood, because of the gradual appearance of vascular malformations. Patients with HHT require complex, multidisciplinary management, because of heterogeneity of clinical manifestations, risk of potentially life-threatening complications and poor prognosis especially in case of multiple visceral teleangiectasia. Here we report a case of severe HTT with diffuse pulmonary arteriovenous malformations in 13-month-old child with negative family history, who presented with polyglobulia and development retardation. On the basis of literature review we present current recommendations for diagnosis and management in HHT, in particularly in the case of diffuse pulmonary arteriovenous malformations, disqualified from any interventional procedures and associated with a poor prognosis.
\end{abstract}

(C) 2014 Polskie Towarzystwo Hematologów i Transfuzjologów, Instytut Hematologii i Transfuzjologii. Published by Elsevier Urban \& Partner Sp. z o.o. All rights reserved.

\footnotetext{
* Adres do korespondencji: Klinika Onkologii i Hematologii Dziecięcej Polsko-Amerykańskiego Instytutu Pediatrii UJ Collegium Medicum w Krakowie, ul Wielicka 265, 30-663 Kraków, Polska.

Adres email: mcwikli@op.pl (M. Ćwiklińska).

http://dx.doi.org/10.1016/j.achaem.2014.04.016

0001-5814/@ 2014 Polskie Towarzystwo Hematologów i Transfuzjologów, Instytut Hematologii i Transfuzjologii. Published by Elsevier Urban \& Partner Sp. z o.o. All rights reserved.
} 
Wrodzona naczyniakowatość krwotoczna (Hereditary Haemorrhagic Telangiectasia; HHT) jest uwarunkowaną genetycznie chorobą naczyń krwionośnych, którą cechują nawracające, uporczywe krwawienia z nosa, obecność patologicznie poszerzonych drobnych naczyń (teleangiektazji) na skórze i śluzówkach oraz malformacji tętniczo-żylnych w narządach wewnętrznych [1-6]. Objawy choroby narastają wraz z wiekiem osób obarczonych mutacją i mogą prowadzić do przewlekłej niedokrwistości z niedoboru żelaza, uzależnienia od przetoczeń masy czerwonokrwinkowej, a niekiedy zagrażających życiu powikłań, w tym niedokrwiennych incydentów OUN i ropni mózgu. Choroba zazwyczaj jest rozpoznawana w okresie 3.-4. dekady życia, a opisy HHT u małych dzieci są bardzo rzadkie [2, 4, 6, 7].

Celem pracy jest prezentacja przypadku ciężkiej wrodzonej naczyniakowatości krwotocznej z obecnością mnogich przetok tętniczo-żylnych w obu płucach, uniemożliwiających ich embolizację i resekcję, którą rozpoznano u małego dziecka, oraz przegląd aktualnej literatury.

\section{Opis przypadku}

13-miesięczny chłopiec z nieobciążającym wywiadem okołoporodowym został hospitalizowany w Klinice Onkologii i Hematologii Dziecięcej Uniwersyteckiego Szpitala Dziecięcego w Krakowie $\mathrm{z}$ powodu nadkrwistości. Wywiad w kierunku przebytych zakażeń i alergii był ujemny. Wykonanie morfologii krwi zlecił pediatra, do którego zgłosiła się matka zaniepokojona faktem, że dziecko nie próbuje jeszcze stawać. W badaniu fizykalnym stwierdzono: objawy sinicy centralnej, palce pałeczkowate, teleangiektazje na jednym policzku (Ryc. 1), uogólnione obniżenie napięcia mięśniowego i opóźnienie rozwoju motorycznego (chłopiec sam nie siadał). W wykonanych badaniach laboratoryjnych stwierdzono między innymi: podwyższenie wartości hematokrytu (Ht - 56,9\%), hemoglobiny ( $\mathrm{Hb}-19,2$ g/dl) i retikulocytów (12-30\%), hipoksemię krwi tętniczej $\left(\mathrm{pO}_{2}-51,3 \mathrm{mmHg}\right)$, podwyższenie stężenia erytropoetyny (186 mIU/ml), brak patologii hemoglobiny,

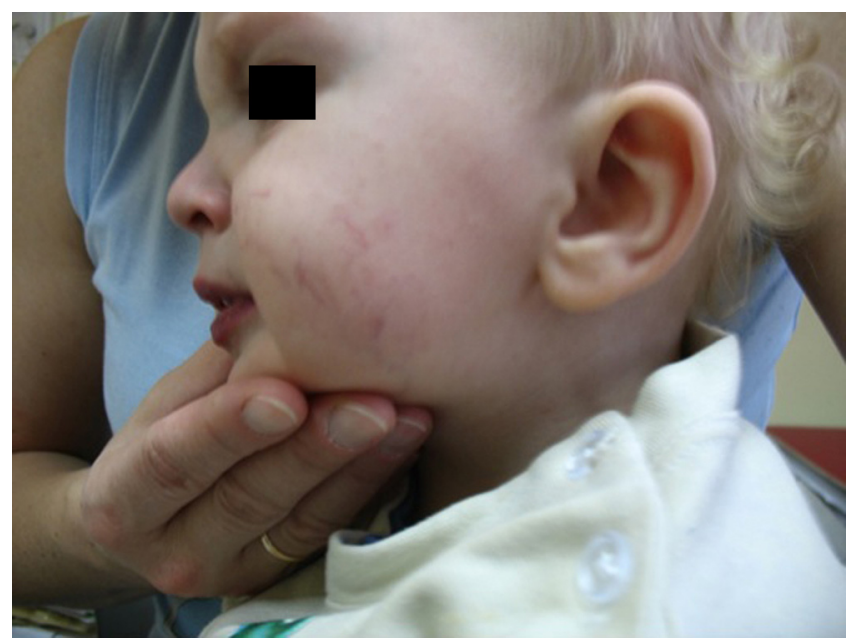

Ryc. 1 - Wstępne objawy choroby obecne u dziecka w wieku 13-miesięcy

Fig. 1 - Prodromal signs of disease in 13-month aged child niskie stężenia Fe i ferrytyny, cechy wyrównanej kwasicy metabolicznej i prawidłowy obraz szpiku kostnego. Wyniki: CK, profilu aminokwasów i acylokarnityn w suchej kropli krwi (tandem MS), profilu kwasów organicznych w moczu (GC-MS), badania EMG oraz MRI mózgowia i rdzenia kręgowego w odcinku Th-S były prawidłowe. Wykluczono siniczą wadę serca i dużych naczyń oraz ektopową produkcję erytropoetyny i nieprawidłowość naczyń nerkowych. Próba tlenowa z wentylacją tlenem $6 \mathrm{l} / \mathrm{min}$ powodowała szybki wzrost saturacji $\mathrm{Hb}$ tlenem z 85\% do 95\%. Wykonano TK HR płuc, które wykazało wzmożony rysunek zrębu płuc o niejasnej etiologii (Ryc. 2). Dziecko zakwalifikowano do cewnikowania serca z angiografią naczyń płucnych, która uwidoczniła obecność licznych, rozsianych malformacji tętniczo-żylnych w obu płucach (Ryc. 3). Obecność mnogich zmian naczyniowych w obu płucach i teleangiektazji na policzku, mimo ujemnego wywiadu rodzinnego i braku krwawień z nosa, pozwoliła wysunąć podejrzenie rzadkiej wrodzonej skazy naczyniowej, choroby Rendu-Osler-Webera. Po wyjaśnieniu przyczyny nadkrwistości odstąpiono od upustów krwi, włączono kwas acetylosalicylowy i preparat żelaza, rozpoczęto rehabilitację ruchową, zaplanowano diagnostykę molekularną oraz zalecono profilaktykę antybiotykową przed inwazyjnymi procedurami i zabiegami. Chłopczyk wraz z zapisem obrazu angiografii naczyń płucnych został skonsultowany w pediatrycznym ośrodku kardiologii inwazyjnej. Mnogi i rozsiany charakter malformacji naczyniowych obecnych w obu płucach uniemożliwił zarówno embolizację przetok i jakiekolwiek formy leczenia operacyjnego (resekcja zajętego miąższu płuc). W uzupełnieniu diagnostyki wykonano badanie MRI mózgowia z sekwencją gradientową, które wykluczyło obecność zmian naczyniowych w tej lokalizacji. W wyniku podjętej rehabilitacji ruchowej chłopiec w wieku 18 miesięcy zaczął wstawać. Zrealizowano rozszerzony kalendarz szczepień ochronnych. W trakcie ponad 3-letniej obserwacji stwierdza się progresję objawów: w 2. roku życia u dziecka pojawiły się pierwsze, epizodyczne krwawienia z nosa, stopniowo narasta

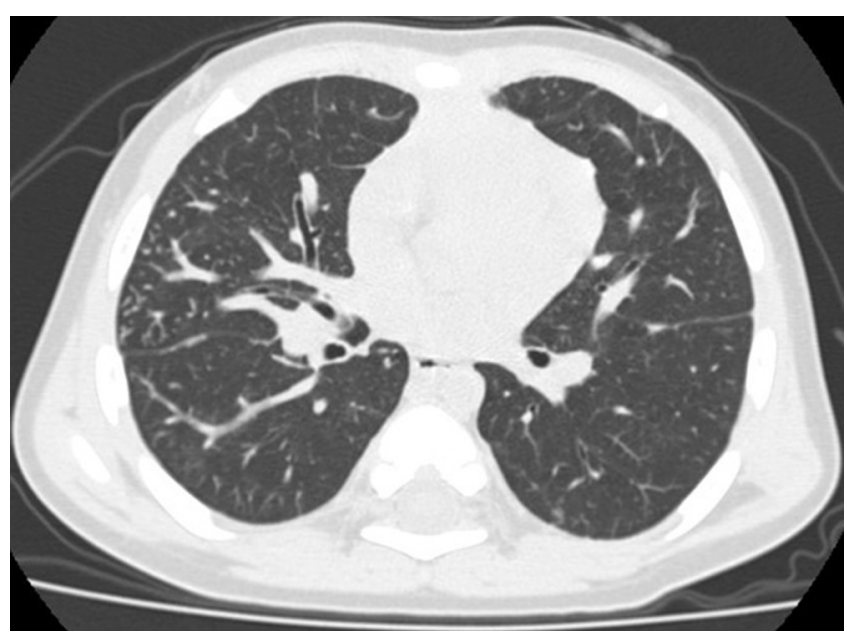

Ryc. 2 - Obraz TK HR płuc: poszerzone naczynia obwodowe w środkowym polu pluca prawego i liczne zmiany drobnoguzkowe podopłucnowo w tej lokalizacji Fig. 2 - CT scan imaging: dilated laterals blood vessels in median field of right lung and multiple subpleural nodules 


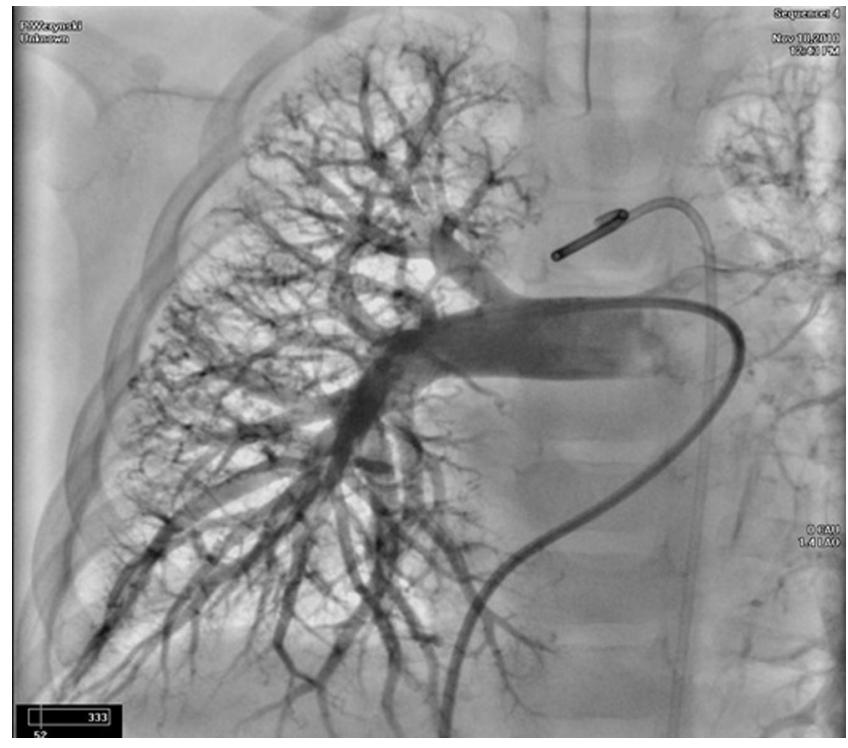

Ryc. 3 - Obraz angiograficzny płuca w trakcie cewnikowania serca: obecność licznych małych przetok tętniczo-żylnych w płucu prawym

Fig. 3 - Pulmonary angiografic imaging of lung: multiple smalls pulonary arteriovenous malformations in right lung

ilość teleangiektazji na skórze (mnogie na obu policzkach, pojedyncze na kończynach i tułowiu). Nadal nie ma ich na języku, śluzówkach jamy ustnej ani palcach. Chłopiec pozostaje w regularnej kontroli ambulatoryjnej: hematologa, kardiologa, pulmonologa, neurologa i rehabilitanta. Rozwija się prawidłowo, jest aktywny i rzadko choruje, a wtórna poliglobulia ma stabilny charakter (Ht - 68\%, Hb - 22-24 g/dl). Do chwili obecnej z powodu braku możliwości wykonania badań genetycznych nie udało się wyjaśnić charakteru mutacji, stanowiącej molekularne podłoże choroby u dziecka.

\section{Omówienie}

Izolowana nadkrwistość zdarza się rzadko u dzieci, zwykle ma ona charakter wtórny wobec przewlekłych zakażeń lub niedotlenienia w przebiegu siniczych wad serca i naczyń lub chorób płuc. Początkowo tylko podejrzewana, do czasu pojawienia się samoistnych krwawień $\mathrm{z}$ nosa, a następnie zdiagnozowana u dziecka HHT, zwana także chorobą Rendu-Osler-Webera występuje z częstością 1:5000 i jest dziedziczona jako cecha autosomalna dominująca $[1-3,5,8]$. U rodziców ani rodzeństwa chłopca nie stwierdzono objawów HHT, a zatem u dziecka musiała mieć miejsce rzadko spotykana spontaniczna mutacja. Warto podkreślić, że wywiad rodzinny dotyczący rodzeństwa i krewnych pierwszego stopnia nie powinien ograniczać się do pytania o teleangiektazje i krwawienia z nosa. Należy uwzględnić w nim m.in. niewyjaśnione zgony we wczesnym dzieciństwie, objawy neurologiczne, niewydolność serca czy epizody krwawienia z przewodu pokarmowego [9]. Defekt budowy endotelium naczyniowego tłumaczy główne objawy choroby, do których należą zgodnie z opublikowanymi w 2000 roku kryteriami Curaçao: mnogie teleangiektazje w charakterystycznej lokalizacji (wargi, jama ustna, nos, palce), spontaniczne i nawracające krwawienia z nosa, malformacje drobnych naczyń krwionośnych narządów wewnętrznych (płuca, wątroba, przewód pokarmowy, OUN) oraz dodatni wywiad rodzinny dotyczący krewnych pierwszego stopnia (rodzice, rodzeństwo, dzieci) w kierunku naczyniakowatości krwotocznej [1, 3, 5, 6, 9, 10]. Choroba najczęściej występuje $\mathrm{w}$ typie 1 związanym $\mathrm{z}$ mutacją genu ENG na chromosomie 9 (białka endogliny) lub typie 2 wywołanym mutacją genu ALK1 na chromosomie 12 (kodującego białko związane z receptorem TGF- $\beta$ ). Te i rzadziej opisywane mutacje (jak SMAD4 pozostająca w związku z młodzieńczą polipowatością) dotyczą genów białek czynników wzrostu komórek endotelium naczyniowego (VEGF), pełniącego kluczową rolę w angiogenezie i procesach naprawczych naczyń. Dlatego prowadzone są badania kliniczne nad zastosowaniem w HHT bevazicimubu (Avastin), rekombinowanego przeciwciała monoklonalnego hamującego angiogenezę, a także thalidomidu, interferonu i estrogenów [3]. Jak wykazano w badaniach na zwierzętach, nieprawidłowe dojrzewanie naczyń w tej chorobie prowadzi do powstawania w skórze, błonach śluzowych, a także w narządach wewnętrznym (płuca, mózg, wątroba, przewód pokarmowy, rdzeń kręgowy) bezpośrednich połączeń pomiędzy małymi naczyniami tętniczymi i żylnymi z pominięciem łączących je fizjologicznie kapilar. Naczynia żylne i tętnicze są znacząco poszerzone, a ich ściany przebudowane $\mathrm{z}$ brakiem włókien kolagenowych. Na skórze i śluzówce języka, nosa, pod paznokciami te nieprawidłowe połączenia naczyniowe widoczne są pod postacią 1-2 mm czerwonych plamek, które $\mathrm{w}$ przeciwieństwie do wybroczyn znikają pod wpływem lekkiego ucisku [1, 3-5]. Przebieg choroby, początek objawów klinicznych i zakres zmian w narządach wewnętrznych są indywidualnie zmienne. Typ 1 HHT charakteryzuje się występowaniem $\mathrm{u}$ młodszych osób krwawień $\mathrm{z}$ nosa i objawów związanych z obecnością malformacji tętniczo-żylnych płuc (PAVMs), a typ 2 cechują typowe objawy ze strony wątroby [1, $4,6,11]$. Niektórzy autorzy wysuwają hipotezę, że na tworzenie się malformacji naczyniowych mogą mieć wpływ dodatkowe czynniki, m.in. środowiskowe. Tłumaczyłoby to typowo spotykaną lokalizację teleangiektazji: w nosie i na wargach narażonych na urazy, przewlekłe stany zapalne i zranienia. Z kolei najczęstszą narządową lokalizację malformacji naczyniowych typowych dla HHT w płucach i mózgu mogłaby tłumaczyć stała, w tym przypadku nieprawidłowa angiogeneza zachodząca w nich po urodzeniu [1] W wielu przypadkach HHT diagnostyka genetyczna nie jest wykonywana, podobnie jak u opisanego dziecka $\mathrm{z}$ powodu braku dostępności, czasochłonności „skiringu”, heterogenności locus mutacji i kosztów testów molekularnych, które w około 70-90\% przypadków mogą zidentyfikować charakter mutacji [1, 3, 6, 9]. Testy genetyczne są szczególnie przydatne $u$ dzieci i młodych dorosłych, u których nie występują jeszcze krwawienia $z$ nosa $i$ nie są widoczne teleangiektazje $\mathrm{w}$ przypadkach obciążającego wywiadu rodzinnego $[2,6]$. Mutacje de novo są rzadkie, dlatego wnikliwy wywiad rodzinny stanowi kluczową rolę w diagnostyce HHT i winien skupiać się także na przypadkach subklinicznych, związanych $\mathrm{z}$ niepełną penetracją genową mutacji [3]. U dzieci z ujemnym wywiadem rodzinnym, podobnie jak w opisanym przypadku, diagnoza HHT jest szczególnie trudna, także dlatego, że 
objawy choroby początkowo są nikłe, a narastają wraz z wiekiem i postępującą pełną penetracją defektu genetycznego [6]. U opisanego dziecka, zgodnie z kryteriami Curaçao, wstępnie do czasu pojawienia się w wieku 19 miesięcy samoistnych nawracających krwawień z nosa możliwe było tylko podejrzenie choroby (spełnione 2 kryteria).

Najczęstszym objawem HHT dotyczącym do 95\% pacjentów są krwawienia $\mathrm{z}$ nosa $[2,6,11,12]$. Występują $\mathrm{z}$ różną częstością, spontanicznie, w sposób nawracający, w różnych porach doby, ze zmiennym nasileniem i konsekwencjami (przewlekła niedokrwistość $\mathrm{z}$ niedoboru żelaza, obniżenie jakości życia, problemy społeczne). Krwawienia z nosa bardzo rzadko występują u małych dzieci, jak w obecnie przedstawianym przypadku. Pojawiają się zwykle w okresie pokwitania, mediana wieku dla tego objawu według danych literaturowych to 12. rok życia; w 4. dekadzie życia występują już u wszystkich pacjentów, co wiąże się $\mathbf{z}$ pełną penetracją mutacji $[2,6,11$, 13]. Postępowanie terapeutyczne poza stałą profilaktyczną higieną śluzówki nosa (nawilżanie i oczyszczanie) polega na stosowaniu: miejscowych żeli i gąbek hemostatycznych, kwasu tranksenamowego, estrogenów i progesteronu, wykonywaniu tamponady, zabiegów koagulacji, embolizacji naczyń i dermoplastyki nosa [2, 11]. Niestety żadna $z$ tych metod nie jest w pełni skuteczna, a długotrwała opieka nad pacjentami z ciężkimi, nawracającymi krwawieniami z nosa wciąż wymaga optymalizacji $[1,2,12]$.

Przetoki tętniczo-żylne obecne w licznych segmentach płuc (PAVMs) występują częściej u osób z mutacją genu endogliny (typ HHT 1) i dotyczą nawet 75\% pacjentów [1]. Standardem diagnostycznym PAVMs jest transtorakalna echokardiografia z kontrastem i niskodawkowana spiralna tomografia płuc wysokiej rozdzielczości, która wykazuje charakterystyczny, zmieniony obraz miąższu płuc, co zostało stwierdzone także w opisywanym przypadku [1, 4, 6, 7, 9, 13]. Przetoki naczyń płucnych mogą być asymptomatyczne lub powodować duszność, hipoksemię i sinicę centralną związaną z przeciekiem prawo-lewym, podobnie jak u obecnie przedstawianego chorego. W takich przypadkach niezależnie od wieku istnieją wskazania do interwencji chirurgicznej, która ma zapobiegać możliwym powikłaniom, takim jak: krwawienia do opłucnej i światła oskrzeli, nadciśnienie płucne, a nawet zagrażającym życiu incydentom zatorowości naczyń mózgu, udarom niedokrwiennym i ropniom mózgu [2-4, 7, 14]. Ryzyko tych powikłań jest szczególnie duże w przypadku mnogich PAVMs oraz gdy ich średnica przekracza $3 \mathrm{~mm}$. Badania publikowane przez Latino i wsp. [4] wykazały, że choć ilość PAVMs (podobnie jak teleangiektazji skórnych) zwykle narasta $\mathrm{z}$ wiekiem, podobnie jak objawy związane $z$ ich obecnością, to przetoki płucne, jeśli występują u pacjenta z HHT, to są obecne już u małych dzieci. Dlatego też podkreśla się konieczność diagnostyki w tym kierunku także u pacjentów z rozpoznaniem HHT obciążonych dodatnim wywiadem rodzinnym, a nie prezentujących jeszcze objawów choroby. Tylko w przypadkach zlokalizowanych zmian możliwe jest leczenie $\mathrm{z}$ zastosowaniem: embolizacji przetok drogą cewnikowania, resekcji segmentów lub płata chorego płuca. Występowanie licznych, rozsianych przetok, tak jak u opisanego dziecka, stanowi przeszkodę w wykonywaniu tych zabiegów i istotnie pogarsza rokowanie [2, 4, 7, 8, 14]. Obecność mnogich PAVMs w niektórych krajach, np. Japonii, stanowi wskazanie do kwalifikacji pacjenta do przeszczepienia obu płuc i to nawet w przypadku współistnienia malformacji w OUN lub przewodzie pokarmowym. Fukushima i wsp. [14], opisując sukces transplantacji obu płuc u 18-letniej pacjentki z HHT, podkreślają, że w okresie 3 lat po przeszczepieniu doszło do niewyjaśnionej regresji malformacji naczyniowych w obrębie mózgu i wątroby. Opisy takich zabiegów, przeprowadzonych z sukcesem, należą jednak w dostępnej literaturze do niezwykle rzadkich, a już zupełnie wyjątkowo dotyczą dzieci z HHT [9, 14]. Dlatego optymalna strategia terapeutyczna w przypadkach mnogich przetok płucnych u dzieci jest wciąż przedmiotem kontrowersji. Jednoznaczne zalecenia dotyczą natomiast prewencyjnej antybiotykoterapii przed zabiegami operacyjnymi i stomatologicznymi, podobnie jak w wadach zastawek serca [2, 7, 14].

Zaleca się, by dzieci z pewnym rozpoznaniem HHT miały przeprowadzoną po 6. roku życia diagnostykę obrazującą OUN z użyciem MRI z kontrastem celem wykrycia ewentualnych malformacji naczyń w obrębie mózgu lub rzadszych w rdzeniu kręgowym. Te same wskazania dotyczą kobiet z HHT, u których przed pierwszą ciążą należy także wykluczyć obecność PAVMs. Choć malformacje naczyniowe w obrębie OUN dotyczą tylko około $23 \%$ pacjentów, z uwagi na ryzyko zagrażających życiu powikłań, jakie mogą powodować w każdym przypadku HHT, zaleca się diagnostykę w ich kierunku. Rozpoznane powinny być leczone metodami mikrochirurgii, embolizacji, stereotaktycznego napromieniania [2]. Ryzyko związane $\mathrm{z}$ wykonywaniem tych zabiegów jest istotnym argumentem za tworzeniem ośrodków dysponujących wiedzą, możliwościami technicznymi i doświadczeniem w różnych metodach postępowania terapeutycznego w HHT.

Dostępna literatura związana z HHT rzadko dotyczy licznych grup pacjentów [10]. Na szczególną uwagę zasługuje praca Faughnana i wsp. [2] powstała na kanwie konferencji w Toronto w 2006. Dzięki dyskusji panelu ekspertów i pracy grup roboczych wypracowano międzynarodowe rekomendacje postępowania diagnostycznego i terapeutycznego w tej rzadkiej chorobie. Wiele krajów zachodnich realizuje zalecenia tych ekspertów, którzy podkreślają celowość opieki nad chorym z HHT w wyspecjalizowanych ośrodkach, dysponujących doświadczeniem wielodyscyplinarnych zespołów z tą rzadką chorobą i jej powikłaniami [1, 2, 8, 12].

\section{Wnioski}

Wrodzona naczyniakowatość krwotoczna jest ciężkim, rzadkim i heterogennym schorzeniem, w którym postępowanie terapeutyczne ogranicza się zazwyczaj po ustaleniu rozpoznania do zapobiegania i leczenia powikłań, które mogą istotnie obciążać jakość życia i rokowanie. Z uwagi na stopniowe ujawnianie się malformacji naczyniowych choroba niezwykle rzadko jest rozpoznawana we wczesnym dzieciństwie. Istnieje konieczność wypracowania także w naszym kraju, zgodnie z zaleceniami ekspertów i wzorem niektórych państw zachodnich, standardów kompleksowej, wielodyscyplinarnej opieki nad pacjentami z HHT. Wydaje się celowe stworzenie w Polsce dla pacjentów pediatrycznych $z$ rozpoznaną chorobą Rendu-Osler-Webera jednego specjalistycznego ośrodka, który zapewniłby im kontynuację opieki w wieku dorosłym. 


\section{Wkład autorów/Authors' contributions}

Według kolejności.

\section{Konflikt interesu/Conflict of interest}

Nie występuje.

\section{Finansowanie/Financial support}

Nie występuje.

\section{Etyka/Ethics}

Treści przedstawione $\mathrm{w}$ artykule są zgodne $\mathrm{z}$ zasadami Deklaracji Helsińskiej, dyrektywami EU oraz ujednoliconymi wymaganiami dla czasopism biomedycznych.

\section{PIŚM I E N N ICT W O/R E FERENCES}

[1] Dupuis-Girod S, Bailly S, Plauchu H. Hereditary hemorrhagic telangiectasia: from molecular biology to patient care. J Tromb Haemost 2010;8:1447-1456.

[2] Faughnan ME, Thabet A, Mei-Zahav M, et al. Pulmonary arteriovenous malformations in children: outcomes of transcatheter embolectomy. J Pediatr 2004;145: 826-831.

[3] Sharathkumar AA, Shapiro A. Hereditary haemorhagic telangiectasia. Haemophilia 2008;14:1269-1280.
[4] Latino GA, Al-Saleh S, Alharbi N, et al. Prevalence of pulmonary arteriovenous malformations in children versus adults with hereditary hemorrhagic telangiectasia. J Pediatr 2013;163:282-284.

[5] Shovlin CL, Guttmacher AE, Buscarini E, et al. Diagnostic criteria for hereditary hemorrhagic telangiectasia (RenduOsler-Weber syndrome). Am J Med Genet 2000;91:66-67.

[6] Van Gent M, Velthuis S, Post MC, et al. Hereditary haemorrhagic telangiectasia: how accurate are the clinical criteria? Am J Med Genet 2013;161:461-466.

[7] Lacombe P, Lacout A, Marcy PY, et al. Diagnosis and treatment of pulmonary arteriovenous malformations in hereditary hemorrhagic telangiectasia: an overview. Semin Interv Radiol 2011;28:24-31.

[8] Shovlin CL. Hereditary haemorrhagic telangiectasia: pathophysiology, diagnosis and treatment. Blood Reviews 2010;24:203-219.

[9] Misra MV, Mullen MP, Vargas SO, Kim HB, Boyer D. Bilateral lung transplant for hereditary hemorrhagic telangiectasia in a pediatric patient. PediatrTranspantation 2012;1-4.

[10] Giordano P, Lenato GM, Suppressa P, et al. Hereditary haemorrhagic telangiectasia: artheriovenous malformations in children. J Pediatr 2013;163:179-186.

[11] Skorek A, Stankiewicz C. Problemy w diagnostyce i leczeniu choroby Rendu-Osler-Webera. Otolaryngologia 2010;9: 155-159.

[12] Sautter NB, Smith TL. Hereditary haemorrhagic telangiectasia-related epistaxis: innovations in understanding and management. Int Forum Allergy Rhinol 2012;2:422-431.

[13] Sekarski LA, Spangenberg LA. Hereditary hemorrhagic telangiectasia: children need screening too. Ped Nursing 2011;37:163-169.

[14] Fukushima H, Mitsuhasi T, Oto T, et al. Successful lung transplantation in a case with diffuse pulmonary arteriovenous malformations and hereditary hemorrhagic telangiectasia. American J Transplat 2013;20:1-4. 